\title{
ONTARIO SCHOOL TEACHERS: A GENDERED VIEW OF THE 1930s
}

\author{
Cecilia Reynolds \\ Harry Smaller
}

\section{Introduction}

This year will be an important one in the professional life of teachers. We have had a check to our best work, and the check is named 'lack of funds.' Are we questioning ourselves and our systems of education to see wherein they have been at fault? ${ }^{1}$

When economic hardships prevail, schools and teachers often fall under scrutiny. While the above quotation might well have been taken from a Canadian newspaper in 1992, in fact it is an excerpt from the The Educational Courier, a teacher union journal, in 1932. This particular article arises out of a longitudinal empirical study on teacher socialization with specific regard to relations of gender, ethnicity, and race. It focuses on a number of observations about Ontario teachers ${ }^{2}$ in the 1930s:

1. The overall percentage of men in teaching rose, but much more so in rural areas than in the cities.

2. Salaries of teachers dropped considerably during this time.

3. There was a significant change in teacher certification procedures, within which gender played a large role. Salaries were also affected by these certification changes.

4. Average ages of teachers increased significantly during this decade.

5. In general, teachers had more years of teaching experience than their colleagues did in the previous decade. However, there were significant gender differences in these figures.

1. Doris French, Highbutton Bootstraps (Toronto: Ryerson Press, 1968).

2. This study confines itself to teachers who worked in the state-funded 'public' schools of Ontario. The provincial government also funded Catholic elementary schools in the province, which in 1928 accounted for approximately sixteen percent of all state-funded, elementary-level students in Ontario. Ontario Department of Education [ODE], Annual Report, 1928. 
6. Both formal and informal policies against the employment of married women as teachers were enforced.

This article details these observations, and then discusses what significance they may have had, in the context of overall 'gender relations' among teachers in Ontario. A number of relevant sources for the 1930s were examined: annual reports of the Ontario Department of Education; annual reports, minutes, and handbooks of the Toronto Board of Education; and contemporary newspapers. In addition, reprinted transcripts of two groups of interviews have been drawn on-six men and women who taught (and later became principals) in Toronto in the $1930 \mathrm{~s}^{3}$ and a number of women teachers from the 1930s who were interviewed for a 1980 s study on women's experiences during the Depression. ${ }^{4}$

\section{The Structure of Ontario Schools in the 1930s}

To begin, we need to place our observations within the wider context of schooling structures in the 1930s and the position of women teachers within those structures. Political, administrative, and financial aspects of school jurisdiction in Ontario were similar to those found in most of Canada and the United States during this period. A provincial department of education had been in existence in Ontario since the mid-1800s, and by the $1930 \mathrm{~s}$, its formal control over teacher training and certification, curriculum and textbooks, school inspection, and similar matters virtually was complete. However, as compared to Australia for example, matters relating to the employment of teachers, including hiring, firing, remuneration, and working conditions, have been (and remain to this day) very much a matter for local school jurisdiction. Until the 1960s, in rural Ontario this control was exercised, not even at the county or township level, but rather within individual 'school sections'-each about two or three miles square. In most cases, each of these autonomous political entities involved only one elementary school, usually containing just one classroom, one teacher, and students from grades one to eight. Each of these village and rural schools was administered by three local school trustees, typically male farmers, elected annually. In 1928, for example, of the 14,055 elementary school teachers in the province, well over half

3. Cecilia Reynolds, 'Naming the Experience: Women, Men and Their Changing Work Lives as Teachers and Principals' (Ph.D. diss., University of Toronto, 1987).

4. Judith Arbus, 'Historical Bases of a Sex-Segregated Labour Force: Women Teachers' Experience During the Great Depression' (M.A. thesis, University of Toronto, 1984). 
$(7,627)$ were employed in villages and rural areas. In most cases, each of these teachers would have been accountable to a different school jurisdiction. ${ }^{5}$

In the context of discussing teachers' work and teachers' lives in the 1930s, it is important to emphasize this structure: 14,055 employees, but at least 8,000 sets of employers. Given this plethora of local relations, and the absence of virtually any provincial regulation over teacher job tenure, salary, benefits, or working conditions, ${ }^{6}$ teachers found themselves almost entirely dependent on the considerations (some would say whims) of these local employers. While some larger towns and cities had developed salary scales and written employment policies by this time (albeit highly gendered in nature, as will be demonstrated below), only a minority of Ontario's teachers 'enjoyed' these benefits during the 1930s.

In addition, directly related to the issue of teachers' work in rural areas was the matter of school financing. While some funding for local schools was available through provincial grants (based mainly on average daily student attendance), much of it was dependent on local property taxation. In times of economic downturn, local ratepayers (including the three who formed each local school board) were understandably reluctant to levy themselves and their neighbours for the funds necessary to pay teachers' salaries. Given this context, and the lack of any effective tenure regulations, it was common practice for some trustees to 'bargain down' teachers' salaries, and/or not renew the contracts of teachers in favour of hiring others willing to be paid less. In some cases, local trustees would instruct teachers to open schools later in the term, and/or close them before the regular end of term, and not pay salaries for the missing weeks or months.

\section{Changes in Gender Relations: Teachers in the 1920s}

It is also important to examine changes in gender relations in the decades leading up to the 1930s. Canada Census data on Ontario teachers reveals that from 1911 to 1951 the percentage of women as compared to men in elementary and secondary schools reached its peak in 1921. As Table 1 shows, statistics on Canada, Ontario, and Toronto over this period reveal that after 1921 there was a

5. ODE, Annual Report, 1928.

6. For further elaboration on these matters, see French, Bootstraps; R.A. Hopkins, The Long March: A History of the Ontario Public School Men Teachers' Federation (Toronto: Baxter Press, 1969); Harry Smaller, 'Teachers, Professionalism and the State in Nineteenth-Century Ontario' (Ph.D. diss., University of Toronto, 1988).

7. In 1930, of the 14,494 teachers in the province, 7,092 were designated 'rural,' and a further 2,641 worked in 'villages and towns'; ODE, Annual Report, 1930. 
steady increase in percentages of men as compared to women in teaching. While social historians in Britain, the United States, and Canada have written about the 'feminization' of teaching up to the 1920s, less attention has been paid to the changes in relationships between men and women teachers as the percentages of men in the teacher workforce gradually increased after that time.

\begin{tabular}{|c|c|c|c|c|c|c|}
\hline \multirow[t]{2}{*}{ Year } & \multicolumn{2}{|c|}{ Toronto } & \multicolumn{2}{|c|}{ Ontario } & \multicolumn{2}{|c|}{ Canada } \\
\hline & $\mathbf{M}$ & $\mathbf{F}$ & $\mathbf{M}$ & $\mathbf{F}$ & $\mathbf{M}$ & $\mathbf{F}$ \\
\hline 1911 & 24 & 76 & 21 & 79 & 19 & 81 \\
\hline 1921 & 31 & 76 & 18 & 82 & 18 & 82 \\
\hline 1931 & 31 & 69 & 23 & 77 & 22 & 78 \\
\hline 1941 & 31 & 69 & 29 & 71 & 25 & 75 \\
\hline 1951 & 38 & 62 & 30 & 70 & 28 & 73 \\
\hline
\end{tabular}

In the decades leading up to 1930 , many women had worked actively to change their traditional patriarchally defined relationships with men. Indeed, this era marked a vigorous struggle among women generally for legal and political rights, and between 1916 and 1920 Canadian women were successful in achieving political enfranchisement in all but two provinces (Prince Edward Island and Quebec). ${ }^{9}$ Historian Jeanne L'Esperance has noted that 'by 1921, there were two women ministers and three other women in two provincial legislatures...It seemed

8. For Britain, see Frances Widdowson, Going Up Into the Next Class: Women and Elementary Teacher Training, 1820-1914 (London: Women's Research and Resources Centre Publication, 1980); for the United States, see Madeleine Grumet, 'Pedagogy for Patriarchy: The Feminization of Teaching,' Interchange 12, 2-3 (1981), and David Tyack and Myra Strober, 'Jobs and Gender: A History of the Structuring of Educational Employment by Sex,' Educational Policy and Management: Sex Differentials, ed. Patricia Schmuck et al. (New York: Academic Press, 1981); for Canada, see Alison Prentice, 'The Feminization of Teaching,' in The Neglected Majority, ed. Susan Mann Trofimenkoff and Alison Prentice (Toronto: McClelland and Stewart, 1977), and Wendy Bryans, 'Virtuous Women at Half the Price: The Feminization of the Teaching Profession and Early Women Teachers' Organizations in Ontario' (M.A. thesis, University of Toronto, 1974).

9. Beth Light and Joy Parr, eds., Canadian Women on the Move, 1867-1920 (Toronto: New Hogtown Press, 1983), 6. 
that the field was open for women to achieve real equality in Canadian life at last.' 10

This surge in political activity was not lost on women teachers-in fact, historians Beth Light and Joy Parr state clearly that, 'among the leadership of women's reform movements, professionals figured prominently-doctors, teachers, and academics.' 11 Women teachers, like other Canadian women, had discovered that collective rather than individual action was often the most effective way to fight for that equality. They had begun to come together in Women's Teachers Associations to meet, talk, and plan actions to improve their situations as teachers. In 1918, the Federation of Women Teachers' Associations of Ontario was formed, to provide an even larger collective for discussion and action. By 1919, over one-third of Ontario's women teachers had voluntarily joined this organization, and equal pay for equal work was a top priority. In 1922, women teachers in Owen Sound, Ontario even threatened to strike for a decent wage. ${ }^{12}$ Indeed, as L'Esperance suggests, 'the 1920 s ended on a note of triumph'13 as the Privy Council in London, England declared that women were 'persons' according to the British North America Act and thus could be appointed to the Canadian Senate. But the fight for change was a struggle. What happened to that struggle in the period of economic downturn in the 1930s? In particular, what changes, if any occurred in relations between men and women teachers in the decade that followed such optimism about women's equality? What lessons can be learned from observations about such struggle?

The remainder of this article involves one important aspect of this overall analysis, the examination of a number of the more 'objective' conditions of gender relations among teachers in the 1930s. These issues include: changes in the proportionate number of men within the teaching population; changes in salary differentials between men and women; changes in the types of teaching/administrative positions in schools; changes in teacher training and certification; changes in the average age of the teacher corps, and in their years of teaching experience. In each instance, we have analyzed these data with a view to examining gender relations; where changes have occurred in these relations during the depression years, we have attempted to provide some possible expla-

10. Jeanne L'Esperance, The Widening Sphere: Women in Canada, 1870-1940 (Ottawa: Public Archives of Canada, 1983), 32.

11. Light and Parr, Canadian Women, 8.

12. Alison Prentice et al., Canadian Women, A History (Toronto: Harcourt, Brace and Jovanovich Canada, 1988), 231.

13. L'Esperance, Widening Sphere, 55. 
nation for this. It is important to note, of course, that this quantitative description and analysis provide only a part of the overall story of gender relations.

\section{More Men in the Teaching Occupation}

As the decade of the 1930s unfolded, it is clear that students saw more and more male teachers in their classrooms. According to Department of Education annual reports, from 1929 to 1939 the proporiton of male elementary school teachers rose from 15.4 percent to 25.3 percent of the overall teaching population. In terms of actual numbers across the province in this ten-year period, male teachers rose from 2,168 to 3,654 , an increase of 1,486, at a time when the number of women dropped by 1,303 (from 12,165 to 10,862 ). ${ }^{14}$

There is no doubt that many of the traditional explanations for the increase of males entering teaching during economic down-times pertain here. Unemployment in the Ontario labour force rose dramatically during these times; there was a hot contest for almost any job which offered any kind of salary, including teaching. In addition, however, across the province males were specifically being encouraged to apply for teaching positions, through a calculated ideological shift in this direction. Several contemporary sources for this era, such as teacher interviews, newspaper reports, and official government statements, suggest that promoting the 'appropriateness' of men becoming teachers was definitely on the agenda, as an accepted and even desirable vocational choice. ${ }^{15}$

Significant changes in the structure of schools and school systems during this time also aided in promoting the 'appropriateness' of men becoming teachers and schooling administrators. In the province overall, many small schools were being closed down, and the students amalgamated into larger school buildings, thus substantially increasing the number of more prestigious and relatively highly paid administrative and specialty teaching positions (principalships, manual training programmes, etc.). ${ }^{16}$ Almost all of these positions were held by men, ${ }^{17}$ and they in turn served as models for aspiring male teachers everywhere. Closely related to this change was the increase of secondary, continuation, and vocational schools in the province, staffed predominately by male teachers. ${ }^{18}$ This further served to 'legitimate' the overall occupation of teaching for males.

14. ODE, Annual Reports, 1929, 1939.

15. For further elaboration on this matter, see for example, Reynolds, 'Naming the Experience.'

16. See for example, data on schools listed annually in ODE, Annual Reports.

17. See, for example, annual yearbooks of the Toronto Board of Education.

18. ODE, Annual Reports. 
There is no doubt that the efforts expended in jurisdictions across the province to hire men were being undertaken at the expense of their female colleagues. In the ten-year period from 1929 to 1939 , at a time when the overall number of teachers in the province dropped slightly (from 14,494 to 14,426), the number of male teachers rose by over sixty-eight percent (from 2,168 to 3,654 )in one respect, this meant a corresponding loss of work for 1,554 women. ${ }^{19}$ Further, these dramatic changes resulted from much more than simple 'proactive' male hiring policies on the part of school boards, to fill positions which legitimately become vacant. In addition, it is clear that, in many quarters, effort was expended in 'creating' vacancies for men to fill. In some instances, resignations were 'voluntarily' submitted by employed female teachers, as the result of moral or administrative suasion of the 'need' to hire 'breadwinning' males. In addition, a number of cases have been cited of women teachers being forced out of their posts involuntarily, through firings or 'non-renewal' of annual contracts, by trustees anxious to replace them with male teachers. Given that the majority of teachers in the province worked for small rural school sections, few of which had any regulations or policies relating to job tenure, these firings were, technically at least, not difficult for school trustees to accomplish. ${ }^{20}$

In urban areas, very different dynamics were at work, in the context of gender relations among the teaching staff. While the proportion of male teachers in urban schools rose less dramatically than in rural settings, the larger cities of Ontario did see an increase of males-from 18.6 percent to 22.9 percent of the overall teacher population in the period from 1930 to 1937. There are a number of reasons for this less significant shift to males in the urban context. First, some larger school boards did maintain policies pertaining to the hiring, placement, remuneration, promotion, and dismissal of teachers. Where such policies existed, and continued to be observed, they probably mitigated against the more overt coercion of individual women teachers to relinquish their posts in favour of men. In addition, women teachers in several Ontario cities had established their own local associations, and these organizations likely were effective in mitigating against arbitrary action on the part of employees. ${ }^{21}$

However, other forces were also at work against women in this regard. Well known in Toronto, for example, were the explicit 'marriage bans' against women teachers. Under these policies, married women could not be hired as teachers. Even more insidious, women teachers already in the employ of the Board were

19. ODE, Annual Reports, 1929, 1939.

20. For further discussion of this issue, see for example, French, Bootstraps, and Bryans, 'Virtuous Women.'

21. See, for example, Harriet Johnston, Jessie P. Semple, and A.A. Gray, The Story of the Women Teachers' Association of Toronto (Toronto: Thomas Nelson and Sons, 1932). 
required to resign their positions upon getting married, regardless of their previous length of tenure. ${ }^{22}$

Ironically, another reason why the percentage of male teachers in the large urban boards did not increase as dramatically as in the rural areas, resulted from the fact that the larger boards historically had employed a greater proportion of male teachers. The reasons for this related directly to the manner in which teaching staffs were arranged in city schools. In almost every case, a larger number of female teachers, responsible for large classes of younger students, were supervised by a smaller number of male teachers, who taught relatively small classes of older students. ${ }^{23}$

If Toronto is any example, these women teachers were further discriminated against by virtue of the manner in which the board's salary schedules were constructed. Higher salaries were allocated to teachers of the higher grade levels-who, in most instances, were males. Even in cases where specially trained teachers were hired for special programmes in the elementary schools (eg., manual training, home economics, kindergarten), male teachers were paid much more than their female counterparts, regardless of the fact that both groups had equally lengthy educational and training backgrounds. ${ }^{24}$

\section{Changes in Salaries}

There is no question that even those teachers who were fortunate enough to keep a position during the Depression suffered from salary cuts, especially those in rural areas. Judging from the overall picture provided by the annual Department of Education reports, salaries for both male and female rural teachers dropped by approximately 38 percent between 1930 and 1936. In the case of women, the average annual wage dropped from $\$ 1,008$ to $\$ 650$, while men went from $\$ 1,208$ to $\$ 745$. $^{25}$ However, as is often the case, these official averages conceal almost as much as they reveal-especially in relation to the range of salaries which teachers received. And there is certainly no doubt that women teachers suffered the most in this regard. For example, while the average wage for female rural teachers in 1936 was officially reported as $\$ 650$ per year, a

22. While not necessarily written down, it is probable that marriage bans were in effect throughout most parts of the province during this time. They are discussed in more detail in a later section of this article.

23. See, for example, Johnston et al., The Story of the Women Teachers' Association; minutes of the Women Teachers' Association of Toronto.

24. See, for example, the annual yearbooks of the Toronto Board of Education, listing each teacher by school, including certificate held, grade/subject taught, years of teaching experience, and salary.

25. ODE, Annual Reports, 1930, 1936. 
representative of the teachers' union complained that there were still 'too many at $\$ 300 .^{, 26}$

\section{Training and Certification-Changes and Implications}

Almost coincidental with the introduction of provincial controls over teacher training and certification in the mid-nineteenth century, the Department of Education entered into a long-term project of 'upgrading' the qualifications required for entering and leaving teacher training programmes, as well as upgrading the 'level' of certificates awarded to teachers. To be sure, there were often setbacks in this overall plan, usually occurring in times of economic upturn, when other, higher paying jobs were available. On these occasions, potential teachers were not motivated to attend teachers' colleges, and the supply of certificated teachers was found so wanting that standards for hiring had to be lowered. By the 1930s, however, a number of major steps had been taken toward 'improving' the 'quality' of teachers in the province, including the closing of the Model Schools at the turn of the century, elimination of the third-class certificate, and finally an increase (albeit temporary) in the length of the teacher training programme from one to two years in $1930 .^{27}$

It is important to examine the ways in which these changes in training and certification affected gender relations among teachers in the province, and especially during the period of the 1930s depression. Historically, women students in the normal schools were over-represented in the programmes which led to only second-class teaching certificates. ${ }^{28}$ There were a number of reasons for this, most relating to the overall ideology of the 'proper' role of women teachers. Men were always considered to be the more desired teachers, a situation that left women with a more tenuous hold on their own employment prospects. Second, given the pervasive marriage ban which existed within the provincial school system, women understandably realized that it would be unlikely that they would be able to continue in teaching were they to get married. Third, promotion within schools was clearly an opportunity reserved only for male teachers, regardless of the abilities, experience, or qualifications of their female counterparts. For all these reasons then, it is understandable why women would be reluctant to invest an extra commitment of time, expense, and energy into their own teacher training.

26. The Educational Courier 5, 1, p. 17.

27. For further details on these changes, see for example, J.G. Althouse, 'The Ontario Teacher, A Historical Account of Progress, 1800-1910' (D. Paed. thesis, University of Toronto, 1929; reprinted, Toronto: Ontario Teachers' Federation, 1967).

28. ODE, Annual Report, 1932, 105. 
Given the realities of the work-place, there was clearly little if any, reason to move beyond the basic requirements needed for employment. ${ }^{29}$

During the decade from 1927 to 1937, however, the proportion of elementary school teachers holding first-class certificates virtually tripled, from 15.8 percent to 46.5 percent of all teachers. ${ }^{30}$ While data is not available to indicate gender differences in this regard, it is clear that, among this group, the proportion of women teachers holding first-class certificates also increased considerably. Regardless of the reasons, suggested above, why women felt it would not be worthwhile to pursue higher accreditation, during times of teacher surpluses and intense job competition, it is clear that any extra advantage might possibly prove useful in the hopes of acquiring a position. ${ }^{31}$

\section{Patterns by Age and Gender Groupings}

In undertaking an exploration of the change in gender relations among teachers over the Depression years, it is also important to take into consideration other demographic data, including age sets, and lengths of teaching experience. Toronto teachers were considerably older than those found in the province in general.

The older ages of Toronto teachers are most likely explained by the longer stay of teachers in urban as compared to rural schools, and the likelihood that Toronto was able to recruit older and more experienced teachers because, as at least one observer who worked in the Board in this period commented, 'Usually you had to work outside for a while before Toronto would take you. They could insist on experience.' Interestingly, while this pattern pertained to each of the five men in a recent interview study of Toronto teachers from this period, two out of the five women interviewed in the same study indicated that they began

29. Judging from a number of primary and secondary sources, it is also understandable why women would not have seen teacher training institutions as useful sites for further personal and/or educational development, or as locations where they would be treated equitably. See, for example, Alison Prentice, "Friendly Atoms in Chemistry": Women and Men at Normal School in Mid-Nineteenth-Century Toronto,' in Old Ontario: Essays in Honour of J.M.S. Careless, ed. David Keane and Colin Read (Toronto: Dundurn Press, 1990); Althouse, The Ontario Teacher.

30. ODE, Annual Report, 1932, 105.

31. During the early 1930 s, the number of women enrolled in the kindergarten training programme at the provincial normal schools also increased somewhat, from an average of 33 (total) per year during the 1920s, to 51 in 1931 and 53 in 1932. However, the number of teachers with such certificates employed throughout the province changed very little during this time (491 in 1927, to a high of 519 in 1937) (ODE, Annual Reports, 1927, 1931, 1932, 1937). 
teaching in Toronto with no previous experience and at a relatively younger age than their male colleagues in the study. How many women teachers were 'exceptions' to this overall pattern and why? Were accepted 'rules' within teachers' understandings of how things worked the same for men and women?

Census data by sex for the province also shows that women teachers were far more likely than men in 1911 to be under twenty-four years of age. Further, although the overall percentage of women in this younger age group steadily declined as it did for men until 1941, there were still considerably higher percentages of female as compared to male teachers in the youngest age group.

Some interesting questions arise from such observations. What were the local realities despite such overall statistics? Were there differences between rural and urban schools, between elementary and secondary schools? How did such age patterns affect relationships between men and women teachers? Did older men take on 'fatherly' roles of protection over their 'daughters'? What were the formal and informal power positions of staff members by combinations of such things as gender, age, and experience? How did salary differentials between men and women affect their views of one another?

Several insights are provided by the men and women from the Toronto Board who remembered their experiences over those years. Agnes, a secondary school teacher, recalled:

The pattern was pretty well set in Toronto and it didn't change much unless a new school was built...A lot of secondary people were old maids, let's face it; so many were older women. Once you got into Toronto, you seldom moved. Unless there was something really drastic, how were they going to get rid of them?...Teachers tended to come in and stay in.

Steven, an elementary teacher, remembered:

The rub came from a few women who were third class, who were helping me learn to teach and they were getting $\$ 700$ and I was getting $\$ 1,600$ and I heard them say: 'Here I am a teacher of experience, helping you a beginner, making $\$ 900$ more than I am.' And I had a very hard road to go there but I don't feel sad about them. They rose above it and so did I, but thank God they did.

Arthur, a secondary school teacher, also indicated that indeed gender and experience had played an important role in his career as a teacher:

Well, men were in short supply. So, I'm not so vain to think it was just my great talents. I taught Math. I was a man. I had experience. Where could you find a man with experience to teach Math? 
It seems then that to understand gender relations amongst teachers in this period it is important to consider the composition of the teacher workforce not only by gender and certification level but also by age and level of experience.

\section{Levels of Experience}

Unfortunately, aggregate statistical data on levels of experience were only found in the Annual Reports of the Ontario Ministry of Education in enough detail to show differences between men and women teachers in rural and urban schools from 1928 to 1932. After 1936, only averages are available and these obfuscate many of the differences noted in the data from the earlier period. What can be observed, however, is that over the decade more males were found in both rural and urban schools in the least experienced (less than one year) and the most experienced (more than forty years) categories.

In the middle ranges of experience, differences can be noted between rural areas where percentages for men and women tended to be highest in the less experienced (one to five years) category and city areas where percentages for men and women were highest in the more experienced (six to thirty-nine years) category. In the case of rural schools, while percentages for males and females are very similar for 1928-30, slightly higher percentages of women in 1929 and 1930 were in the newly hired, inexperienced teacher group. In 1931 and 1932, however, percentages of men in this group are higher than those found for women. In cities, percentages for men and women stay very similar over the period but a gradual increase can be seen in the percentages of men as compared to women in this group. Thus, in both cities and rural areas, from 1930 to 1932 percentages of men in the newly hired inexperienced group increased as compared with percentages of women in this group.

\begin{tabular}{|c|c|c|c|c|c|c|}
\hline \multirow[t]{2}{*}{ Year } & \multicolumn{2}{|c|}{ Rural } & \multicolumn{2}{|c|}{ Cities } & \multicolumn{2}{|c|}{ Total } \\
\hline & $\mathbf{M}$ & $\mathbf{F}$ & $\mathbf{M}$ & F & $\mathbf{M}$ & $\mathbf{F}$ \\
\hline 1928 & 16.3 & 15.5 & 2.2 & 2.9 & 8.7 & 9.3 \\
\hline 1929 & 12.5 & 14.1 & 1.5 & 2.0 & 6.1 & 8.3 \\
\hline 1930 & 12.4 & 14.0 & 3.4 & 3.1 & 7.0 & 8.4 \\
\hline 1931 & 14.5 & 11.9 & 2.9 & 2.4 & 8.5 & 7.2 \\
\hline 1932 & 16.9 & 10.9 & 1.9 & 0.7 & 9.0 & 5.9 \\
\hline
\end{tabular}


Table 3 shows percentages of teachers in the category of one to five years of experience. Here we note that nearly one-half of all rural teachers over the period were in the one to five-year grouping and percentages of women in this group were greater than those for men. In cities, only about one-quarter of all teachers were in this relatively inexperienced group and it was males who as a group showed higher percentages.

\begin{tabular}{|c|c|c|c|c|c|c|}
\hline \multirow[t]{2}{*}{ Year } & \multicolumn{2}{|c|}{ Rural } & \multicolumn{2}{|c|}{ Cities } & \multicolumn{2}{|c|}{ Total } \\
\hline & $\mathbf{M}$ & $\mathbf{F}$ & $\mathbf{M}$ & $\mathbf{F}$ & $\mathbf{M}$ & $\mathbf{F}$ \\
\hline 1928 & 54 & 59 & 26 & 20 & 40 & 43 \\
\hline 1929 & 55 & 59 & 25 & 22 & 39 & 43 \\
\hline 1930 & 64 & 56 & 26 & 22 & 38 & 41 \\
\hline 1931 & 50 & 54 & 25 & 21 & 36 & 39 \\
\hline 1932 & 47 & 51 & 21 & 19 & 34 & 36 \\
\hline
\end{tabular}

Table 4 shows that while only about one-quarter of all nural teachers fell into the mid-range of six to thirty-nine years of teaching experience, the percentages for men in this group were higher. About three-quarters of all city teachers were in this more experienced group and here percentages for women were higher.

\begin{tabular}{|c|c|c|c|c|c|c|}
\hline \multirow[t]{2}{*}{ Year } & \multicolumn{2}{|c|}{ Rural } & \multicolumn{2}{|c|}{ Cities } & \multicolumn{2}{|c|}{ Total } \\
\hline & $\mathbf{M}$ & $\mathbf{F}$ & $\mathbf{M}$ & $\mathbf{F}$ & $\mathbf{M}$ & $\mathbf{F}$ \\
\hline 1928 & 29 & 25 & 69 & 75 & 49 & 47 \\
\hline 1929 & 31 & 27 & 72 & 74 & 56 & 54 \\
\hline 1930 & 23 & 30 & 67 & 73 & 52 & 50 \\
\hline 1931 & 35 & 34 & 70 & 75 & 53 & 53 \\
\hline 1932 & 36 & 38 & 74 & 79 & 56 & 57 \\
\hline
\end{tabular}


In the most experienced group, those with forty or more years of teaching (Table 5), males were more predominant in both rural and city schools but the percentages indicate that these most experienced teachers were more likely to be found in city rather than rural schools.

One possible explanation for these data is the enforcement of a marriage ban on women teachers which would appear to have been more strongly felt among women in rural rather than urban schools. Other implications of this ban are outlined below. Another explanation may be linked to the pattern of initial teaching in rural schools to gain experience and then movement into city schools where teachers spent the remainder of their teaching years.

\begin{tabular}{|c|c|c|c|c|c|c|}
\hline \multirow[t]{2}{*}{ Year } & \multicolumn{2}{|c|}{ Rural } & \multicolumn{2}{|c|}{ Cities } & \multicolumn{2}{|c|}{ Total } \\
\hline & $\mathbf{M}$ & $\mathbf{F}$ & $\mathbf{M}$ & $\mathbf{F}$ & $\mathbf{M}$ & $\mathbf{F}$ \\
\hline 1928 & 1.0 & .07 & 2.2 & 2.8 & 2.4 & 1.2 \\
\hline 1929 & 1.1 & .05 & 2.3 & 2.2 & 2.8 & 1.0 \\
\hline 1930 & 0.9 & .06 & 3.4 & 2.0 & 2.4 & 0.9 \\
\hline 1931 & 0.8 & .03 & 3.4 & 2.2 & 2.2 & 1.0 \\
\hline 1932 & 0.6 & .08 & 3.1 & 2.1 & 2.0 & 1.0 \\
\hline
\end{tabular}

Whatever the explanation, what remains clear is that the local realities of gender relations in rural and urban schools may have been quite different, due in part to these observed differences in patterns by gender and teaching experience.

In an effort to trace patterns in staff changes during the Depression years, Toronto Board of Education Yearbooks and recorded information were used over the time span for four schools in differing sectors of the city. This revealed that, at least in Toronto elementary schools, the pattern was one whereby a highly experienced male was principal of a staff which contained mostly female teachers. Among those women, most were in the mid-range of experience, and some had a great deal of experience which either equalled or surpassed that of the principal. There were very few inexperienced female newcomers. Among the male teachers, most were in the one to five or six to thirty-nine-year categories. Few were inexperienced newcomers and none were as experienced or more experienced than the principal. Over the decade of the 1930s there was not a dramatic shift in this staffing pattern by gender or by experience levels. It was observed, 
however, that numbers of women in the most experienced categories declined while percentages of men in the least experienced group increased slightly.

Table 6 shows average experience figures available over the period and suggests that, overall, city teachers tended to be about three times more experienced than their rural colleagues at the beginning of the period but by the end of the period they were only about twice as experienced as a group. Data displayed in this section suggest that men were increasingly favoured over women in new hiring in both rural and urban areas over these years and they were also more likely to be retained in their positions for longer teaching careers.

\begin{tabular}{|c|c|c|c|c|}
\hline \multirow[t]{2}{*}{ Year } & \multirow[t]{2}{*}{ Rural } & \multirow[t]{2}{*}{ Cities } & \multicolumn{2}{|c|}{ Total } \\
\hline & & & $\mathbf{M}$ & $\mathbf{F}$ \\
\hline 1928 & 4.7 & 13.2 & 9.9 & 8.8 \\
\hline 1929 & 5.3 & 13.6 & 10.6 & 9.3 \\
\hline 1930 & 5.5 & 13.6 & 10.5 & 9.4 \\
\hline 1931 & 5.5 & 13.3 & 10.2 & 9.4 \\
\hline 1932 & 5.8 & 13.9 & 9.9 & 9.9 \\
\hline $1936 / 37$ & 7.3 & 15.9 & 9.8 & 12.6 \\
\hline
\end{tabular}

What did all this mean for relations between male and female teachers of differing levels of certification, age, and experience? Whose voice held sway in discussions about schools or in decisions within the schools? All of the evidence suggests that indeed it was the male teacher whose voice was heard most loudly. In direct competition with men, only a few women on each individual teaching staff or within the local school boards could claim equal positions of legitimated power by such measures as certification, experience, and age. There were separations between men and women which mitigated against their ability to interact on an equal footing. As Madeline, a secondary school teacher in Toronto in the 1930s, remembers:

It was a very cosy staff. There was a women's teachers' lunchroom and a men's teachers' lunchroom. You could smoke in the furnace room...I was the first woman to be allowed to teach Accounting.

Geraldine, also a secondary teacher, recalled: 
We didn't do a lot with the men. They were a lot older than me...When women teachers got married, the social circle changed. Marriage made a difference...I had a leadership role on staff. I got along with the men and the men really made life easy for me...I could roll with the punches.

Geraldine's comments raise a number of questions about relationships between men and women teachers over this period, as well as relations between married and unmarried women.

\section{Married Women Teachers}

During the 1920s and 1930s women teachers faced a number of contradictions about their possible roles as teachers and as mothers. On the one hand, with the establishment of the newly formed Ontario Federation of Women Teachers' Associations, they had the potential of seeing themselves as career women who had the right to work and the right to a wage that was equal to that of men who did the same work. In continuing organizations such as the National Council of Women of Canada, however, motherhood was seen as largely incompatible with waged labour. In fact, it has been noted that 'during the Depression years, when jobs were scarce, the National Council joined other Canadians in arguing that working women should not be competing with men for jobs. ${ }^{, 32}$ As the official historian of the F.W.T.A.O. noted, even members of the women's teachers' federation argued that married women should not be working 'now that there are single girls out of a position. 33

Thus, not only were women teachers discouraged on the one hand from competing directly with men for teaching jobs in these hard economic times, they were encouraged also to see other women as their main source of competition for such jobs. These views served to maintain separate spheres for men and women in teaching and mitigate against their relations as equals, as well as to raise barriers between different groups of women themselves. These differences were also bolstered by what has been called 'the cult of true womanhood' which endorsed the notion of a special, domestic sphere for women. ${ }^{34}$

Ironically, the 'new education' movement in the 1920s and 1930s, which drew heavily on the writings of Pestalozzi and Froebel, encouraged the development of kindergarten and emphasized the mothering role of the teacher. Such mothering, however, was to be done by single women with specialist certificates. In addition, these women were asked to leave their teaching post immediately

32. Prentice et al., Canadian Women, 266.

33. French, Bootstraps, 133.

34. Tyack and Strober, 'Jobs and Gender,' 7. 
upon their marriage unless they could prove that their husbands were unable to support them. Thus, an ideology of the male breadwinner combined with ideas about the cult of true womanhood and policies designed to keep married woman out of teaching.

While census data on teachers are not available by marital status before 1931, Table 7 indicates that during the period 1931-41, very few married women were employed in teaching in Ontario (three to five percent of the total teaching population). These statistics suggest that official policies and practices during the 1930s were very effective in helping to keep most married women teachers out of the occupation. It is very difficult to know the extent to which formal 'marriage ban' policies, such as that established in the Toronto Board of Education in 1925,5 or more informal customs were used, but the overall result was that only in exceptional circumstances in the 1930s would you find married women in an Ontario classroom. Ironically, this situation changed very quickly during World War II, however, as such women were called into service due to a teacher shortage. In the 1940s and 1950s most board policies against married women teachers were rescinded, ${ }^{36}$ but some of the ideas upon which these policies were based remained as part of the culture of school for many years.

\begin{tabular}{|c|c|c|c|c|c|c|c|c|c|}
\hline \multirow[t]{2}{*}{ Year } & \multicolumn{3}{|c|}{ Single } & \multicolumn{3}{|c|}{ Married } & \multicolumn{3}{|c|}{$\begin{array}{c}\text { Widowed/Divorced/ } \\
\text { Separated }\end{array}$} \\
\hline & $\mathbf{M}$ & $\mathbf{F}$ & $\mathbf{T}$ & $\mathbf{M}$ & $\mathbf{F}$ & $\mathbf{T}$ & $\mathbf{M}$ & $\mathbf{F}$ & $\mathbf{T}$ \\
\hline 1931 & 44 & 96 & 84 & 54 & 3 & 15 & 2 & 1 & 1 \\
\hline 1941 & 34 & 93 & 76 & 65 & 5 & 22 & 1 & 3 & 2 \\
\hline 1951 & 26 & 68 & 55 & 75 & 28 & 42 & 0.8 & 4 & 3 \\
\hline 1961 & 26 & 46 & 36 & 73 & 48 & 58 & 0.8 & 5 & 4 \\
\hline 1971 & 22 & 30 & 27 & 77 & 65 & 70 & 1 & 4 & 3 \\
\hline
\end{tabular}

Several aspects of this era of a marriage ban for women teachers merit further discussion. Despite the rhetoric about breadwinners and motherhood which

35. See Cecilia Reynolds, 'Too Limiting a Liberation: Discourse and Actuality in the Case of Married Women Teachers,' in Feminism and Education: A Canadian Perspective, ed. Frieda Forman et al. (Toronto: OISE Press, 1990).

36. Ibid., 160. 
surrounded such customs in the 1930s, we need to examine the symbolic impact this ideology had upon teachers, and its overall relation to changes in teacher demographics over the period.

At a symbolic level, policies requiring married women teachers to resign gave a strong message to any woman who wished to earn a wage as a teacher. Women had only grudgingly been accepted in the teaching occupation as statefunded and compulsory schooling developed in Canada. ${ }^{37}$ They were 'allowed' to teach but were to do so only under the supervision of male principals, trustees, and inspectors. When women teachers started gathering together in their own voluntary associations in the late 1800s, and when by 1921 they made up eighty-two percent of all teachers in the province, the potential existed for lessening of control over them by school officials. The marriage ban, whether by policy or custom, served, however, only to re-assert the power of such officials over women teachers.

The marriage ban also contributed to a division between male and female teachers in at least two ways. First of all, it positioned men and women differently within the teacher workforce. Men, since they were not required to leave upon marriage, were positioned as the more stable, more experienced sector of that workforce. Since they could remain in teaching, and since the ever-enlarging schooling hierarchy promised administrative possibilities, it was a good investment for men to obtain the highest credentials possible within teaching. These investments were highly likely to pay dividends for a number of years. Women, however, largely because they would be required to leave teaching upon marriage, were positioned as temporary and more easily replaceable members of the teacher workforce. They could be called upon when required and easily dispersed when not needed. They could, of course, resist such positioning but this would require resisting marriage and accepting a stigmatized role as a 'spinster teacher.' Thus, the marriage ban mitigated against the usefulness for women of investing in the acquisition of higher credentials for their teaching work.

Second, the marriage ban helped to create and sustain a pattern within school staffs whereby the men were married and the women were single. Such an arrangement mitigated against male and female teachers seeing each other as colleagues, partly because of the threat of sexual innuendo. Separate spheres for men and women teachers developed along grade levels, and across teaching and administrative tasks. ${ }^{38}$

Further data on urban and rural differences in marriage ban customs and policies are needed for us to understand more fully how such policies and practices were played out at the local level. However, it can be argued that

37. For a full discussion, see Prentice, 'Feminization.'

38. See Cecilia Reynolds, 'Man's World, Women's World,' Women's Education des femmes, 7, 3: 29-33. 
policies and beliefs about married women teachers contributed to unequal relations between men and women in the teacher workforce over this period.

\section{Summary}

Relations between men and women teachers were affected adversely during the 1930 s by a number of changes which served to sustain separate and unequal spheres for men and women within the tzacher workforce. These changes included rising certification requirements which were tied to pay differentials. Because this occurred at a time when a marriage ban operated (whether formally or informally) to end most women's teaching careers upon marriage, men and women viewed the usefulness of such certification differently. Also, the developing schooling specialties, such as kindergarten and manual training, were highly gendered and encouraged further separations between men and women teachers.

Related to such shifts in certification were changes in the age groupings of teachers. While the entire teacher population 'aged,' it appears that overall, men remained in the older categories as compared to women. Such observations, however, do not tell us a great deal about the local realities found by men or women in rural and urban schools. We cannot assume that age alone would be sufficient to afford greater power to one group over another. It seems that age, gender, certification, and level of experience need to be considered together.

Consideration of the marriage ban over this decade also suggests that in understanding gender relations, we need to think about relations within gender groups as well as between them. How did married women and single women see one another when they worked on the staff? How did older men view their younger male colleagues? Here again, differences suggested in the overall provincial data may be misleading and investigations are needed of specific schools followed over time in order to ascertain how these relations developed, how they changed, and what impact past traditions continue to have upon present-day gender relations within the teacher workforce. 